\title{
THE CODIFICATION AND RANKING OF DEVELOPMENT STRATEGIES OF IRON AND STEEL INDUSTRIES IN AFGHANISTAN, WITH REGARDS TO INPUTS REQUIREMENTS AND USE OF THE SWOT TECHNIQUE, COMBINING SHANNON ENTROPY AND PROMETHEE METHODS
}

\author{
Salehy S.M. \\ Mining Engineering Department, \\ Faculty of Engineering, \\ Baghlan University, Baghlan, \\ Afghanistan
}

\author{
Aimaq M.B. \\ Mining Engineering Department, \\ Faculty of Engineering, \\ Baghlan University, Baghlan, \\ Afghanistan
}

\author{
Sakaye A.Q \\ Mining Engineering Department, \\ Faculty of Engineering, \\ Baghlan University, Baghlan, \\ Afghanistan
}

Article DOI: https://doi.org/10.36713/epra6973

DOI No: 10.36713/epra6973

\begin{abstract}
Considering the growth of iron and steel industry in the world, existence of iron ore rich resources, abundance of inputs required by the steel industries and higher demands for steel in Afghanistan, the idea of analyzing the strategy of iron and steel industries for codifying and defining of a development strategy in field of respective industries has been created in Afghanistan. Due to, the first strategy of iron and steel industries in the world and in selected countries (China, Iran, India and Pakistan) has been analyzed and evaluated. With the help of library studies, bylaw appraisal and interviews with experts, the effective internal and environmental factors for establishment of iron and steel industries in Afghanistan has been analyzed and determined. Based on the weaknesses and threats of selected countries regarding steel and iron industries and the current internal and environmental factors in Afghanistan, eight bold categories of strategy in respective of development projects in Afghanistan has been defined and codified by using SWOT technique. The Ranking of strategies have been done by using Shannon entropy and Promethee methods. As the result ST $\mathrm{Strategy}_{2}$ placed on first and $\mathrm{SO}_{2}$ Strategy placed on last position.
\end{abstract}

KEYWORDS: Strategic Analysis, SWOT, Shannon entropy method and Promethee method.

\section{INTRODUCTION}

The iron and steel industry were with more than 5,000 years history in the world, and in the present age, its due to many needs to that, in the field of the industrial and constructional activities, it is considered as a comprehensive and infrastructure industry. Iron and steel are a major part of the world's commodity[1]. The iron and steel industry in Afghanistan have not been a good situation, in field of iron and steel industry since yet it has not been made large investment for private and governmental in this country. Only a few small and iron plants started to their activity with private investments in the province of Kabul, it has been involved with the internal needs of the country, Thatcannot supply internal needs. Therefore, in this research, it has been trying to arrange a scientific development strategy for the plan، to plan these programs. 
China is one of the large industrialized countries in the world, and in 2018, producted about $51.3 \%$ of the world's raw steel production[2]. neighborhood with the industrial country, that was also one of the largest countries in importer of iron ore, it has been a good opportunity for Afghanistan to build the iron ore processing industry and the market demand for the region. The iron and steel industry have grown dramatically in global trade transactions, and Afghanistan has been a developmental country, most of its iron ore reserves in high mountains. Comment on research on the natural and mineral resources of Afghanistan, this country has a better future in the iron and steel industry sector[3]. Afghanistan is still an imported country that is unable to provide their domestic needs and about 4,500 tons of steel products import from different countries[4]. On this purpose, the idea of the development plan of the industry has been made in the field of industry. In this research, the analysis and evaluation of the strategy of iron industry and the world steel and the selected countries, at the first landscape and mission, and then the development strategies have been codificationand defined for Afghanistan.

\section{MATERIALS AND METHODS}

The first research process begins with a general evaluation and review of the strategy of the world iron and steel industry. Then the iron and steel industry in selected countries (China, India, Iran and Pakistan) is analyzed and evaluated. The vision, mission and internal and environmental factors affecting the construction of Afghanistan's iron and steel industry are determined by distributing questionnaires and interviewing experts. According to the studies and analysis, first the vision and mission and then the development strategies for Afghanistan are defined and formulated. The general structure of the realization performance process is expressed in Figure 1.

Analysis of the world iron and steel industries and selected countries between 2015-2017

- China

- India

- Iran

- Pakistan

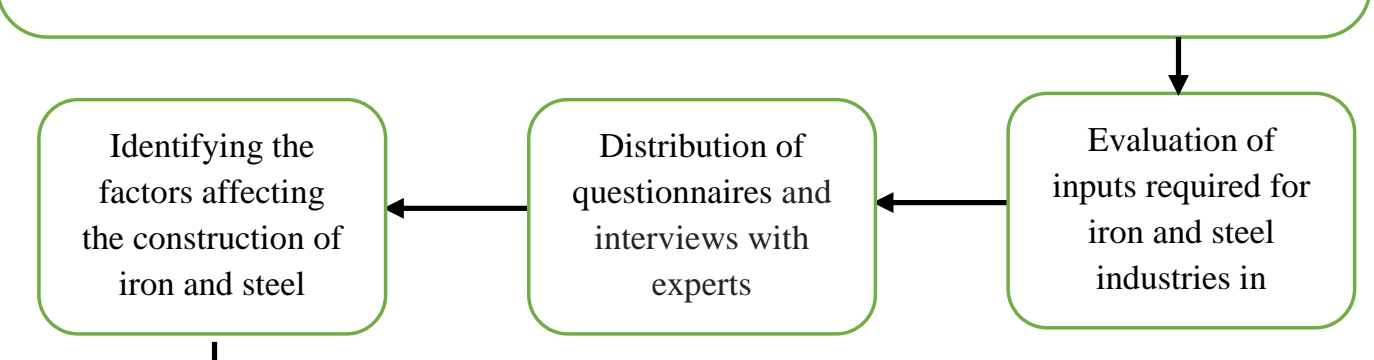

Defining and formulating the vision, mission and development strategies of Afghanistan Iron and Steel Industries using SWOT technique

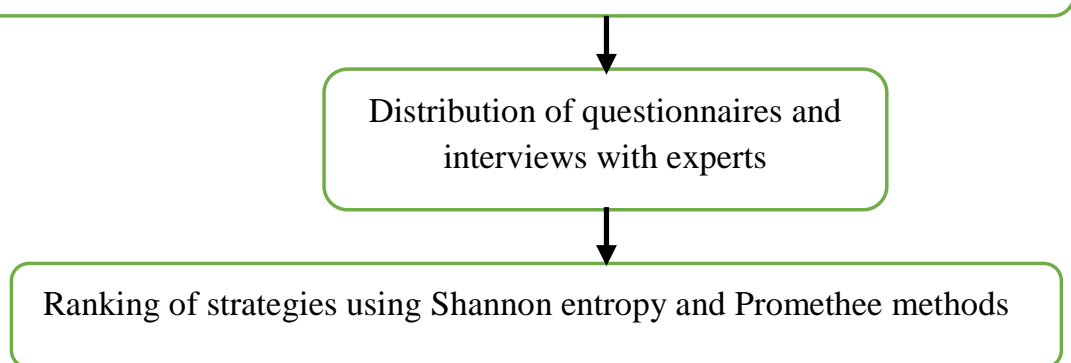

Figure 1: The General Structure of the Research Rotation

\section{2-1. Analysis of the strategy of iron ore and steel industry in selected countries (China, India, Iran and Pakistan)}

According to the analysis process, the first step is to analyze the strategy of the iron and steel industry in selected countries. Including the analysis and evaluation of the iron and steel industry chain in China, India, Iran and Pakistan. 


\section{2-1-1. China Iron and Steel Industry}

Efforts have been existed to the diversify China's steel supply. And Chinese policymakers do encourage direct investment. The Continuous exploration and extraction of iron ore in outside China has been supported by Chinese companies without any break until today, Many Chinese companies which they have large mineral resources in South Africa, America, Central Asia, Russia, Australia and Canada. They have invested[5].

- Vision

An Acceptable Perspective for China, Companies Specializing in Global Classification of Natural Resources Committed to following from international standard, in the field of the Mining operations and Environmental Protection brings and raises the tremendous value for Communities, Investors, Employees and Brings Other Stakeholders[6].

- Mission

The mining sector is responsible for the exploration and exploitation of minerals, the mining operations, the processing of extracted minerals and the provision of comprehensive energy requirements[6].

Finally, the overall evaluation and analysis of China's iron and steel industry, the severe fluctuations observed in various fields of the iron and steel industry. It summarized as the ups and downs of the years 2015 to 2017 and Ithas shown in Table 1.

Table 1: Comparison of the performance of the Chinese iron and steel industry between 2015 up to $2017[2]$.

\begin{tabular}{|c|c|c|c|c|}
\hline \multicolumn{2}{|c|}{ Indicators } & 2015 & 2016 & 2017 \\
\hline \multicolumn{2}{|c|}{ Crude steel production (mt) } & 803.8 & 807.6 & 831.7 \\
\hline \multirow{4}{*}{ 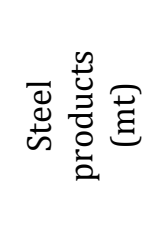 } & Manufacturing & 1683.1 & 1679.7 & 1694.0 \\
\hline & Demand & 672.3 & 665.6 & 672.3 \\
\hline & Importation & 26.2 & 27.1 & 27.7 \\
\hline & Exports & 64.4 & 62.3 & 33.8 \\
\hline \multirow{3}{*}{ 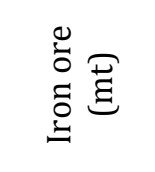 } & Manufacturing & 1381.3 & 1150 & 1229.4 \\
\hline & Exports & - & - & - \\
\hline & Importation & 953.4 & 1024.7 & 1075.4 \\
\hline \multirow{2}{*}{ 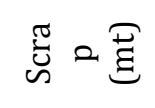 } & Exports & 0.001 & 0.001 & 2.230 \\
\hline & Importation & 2.3 & 2.2 & 2.3 \\
\hline \multicolumn{2}{|c|}{$\begin{array}{c}\text { Per capita consumption of raw steel } \\
\text { per kilogram }\end{array}$} & 501.3 & 505.5 & 544.5 \\
\hline \multicolumn{2}{|c|}{$\begin{array}{l}\text { Per capita consumption of steel used in } \\
\text { kilograms }\end{array}$} & 481.3 & 485.2 & 522.8 \\
\hline \multicolumn{3}{|c|}{ Estimated population in 2019 to million } & \multicolumn{2}{|c|}{1395.41} \\
\hline
\end{tabular}

\section{2-1-2. Indian Iron and Steel Industry}

India has vast resources of metallic and industrial minerals and mining is an important part of India's economy.Minerals product is forming for 1.91 percent of India's GDP. Economic Growth and Demand Levels in india national steel policy has increased steel consumption by 12.5 percent over the past three years, that is faring above from the predicatedpercent 6.9. It is in the national steel policy of India[7].

- Vision

Optimizing the use of Indian mineral resources have been through scientific, sustainable and transparent mining, with geographical research, exploration and preparation, with accompanied by the construction of new factories, the development of previous factories and the supply of domestic and foreign demand[8]

- Mission

For maintain India's position as a major producer of iron and steel, while it is as a quality steel producer Providing and expanding Businesses with Income and Exploitation of Iron ore, Coal and Other Mineral Resources in India and Abroad. It is desirable offer services for investors to be part of the mission[8]. 
After the general evaluation and analysis of the Indian iron and steel industry, sharp fluctuations in various fields of the iron and steel industry have been observed, including the ups and downs from 2015 to 2017 and are summarized in Table 2 .

Table 2: Comparison of Indian Steel and Steel Industry Performance between 2015 to 2017 [2].

\begin{tabular}{|c|c|c|c|c|}
\hline \multicolumn{2}{|c|}{ Indicators } & 2015 & 2016 & 2017 \\
\hline \multicolumn{2}{|c|}{ Crude steel production (mt) } & 89.0 & 95.4 & 101.4 \\
\hline \multirow{4}{*}{ 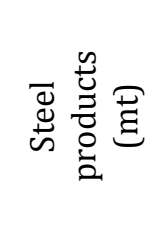 } & Manufacturing & 194.7 & 211.5 & 251.8 \\
\hline & Demand & 80.1 & 84.4 & 89.1 \\
\hline & Importation & 26.5 & 19.8 & 17.7 \\
\hline & Exports & 12.3 & 15.9 & 23.6 \\
\hline \multirow{3}{*}{ 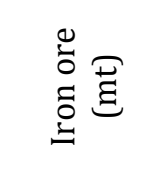 } & Manufacturing & 142.500 & 184.511 & 201.815 \\
\hline & Exports & 4.211 & 21.697 & 28.057 \\
\hline & Importation & 9.515 & 3.597 & 2.358 \\
\hline \multirow{2}{*}{ 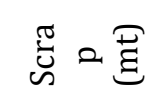 } & Exports & - & - & - \\
\hline & Importation & 6.710 & 6.380 & 5.365 \\
\hline \multicolumn{2}{|c|}{$\begin{array}{c}\text { Per capita consumption of raw steel } \\
\text { per kilogram }\end{array}$} & 68.2 & 71.4 & 75.3 \\
\hline \multicolumn{2}{|c|}{$\begin{array}{l}\text { Per capita consumption of steel used in } \\
\text { kilograms }\end{array}$} & 61.2 & 63.2 & 66.2 \\
\hline \multicolumn{3}{|c|}{ Estimated population in 2019 to million } & \multicolumn{2}{|c|}{1346.95} \\
\hline
\end{tabular}

2-1-3. Iran Iron and Steel Industry

Demand in the steel products market, like some other markets, is divided into two categories, consumer demand and investment demand. Most of the consumer demand is related to infrastructure and construction projects, construction of various machines and vehicles, and the oil and gas industry. Apparent consumption of steel in 2001 was equal to 10.4 million tons, which reached 19.5 million tons in 2013, and thus apparent consumption of steel during this period has experienced an average annual growth of 4.9 percent[9].

- Vision

Vision to horizon 2025, It is one of the leading groups in international trade, domestic industry and global markets, development and Technology transfer[10].

- Mission

The Mining Division is responsible for producing the National Geosciences Database, identifying resources, exploring reserves, optimizing extractions and maintaining mines, developing of the processing industry, supplying raw materials to the industries mineral and other related industries, as well as expanding Iran's mining activities inglobally level, and It is for increase of the national wealth and public welfare[10].

Iran's iron and steel industry has experienced ups and downs in recent years, including the production, consumption and exports have adopted the upward and imports downward. In this study the fluctuations summarizeswhich has begun in the Iranian iron and steel industry from 2015 to 2017 and presented in Table3.

Table 3:Compares the performance of the Iranian iron and steel industry between 2015 to 2017 [2].

\begin{tabular}{|c|c|c|c|c|}
\hline \\
\hline & icators & 2015 & 2016 & 2017 \\
\hline \multicolumn{2}{|c|}{ Crude steel production (mt) } & 16.146 & 17.895 & 21.236 \\
\hline \multirow{3}{*}{ 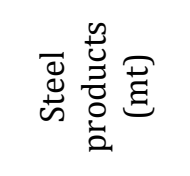 } & Manufacturing & 30.3 & 30.9 & 31.8 \\
\hline & Importation & 9.7 & 9.4 & 6.2 \\
\hline & Exports & 5.8 & 10.2 & 14.7 \\
\hline$=0 \leqslant 0\}$ & Manufacturing & 39.370 & 43.280 & 55.087 \\
\hline
\end{tabular}


EPRA International Journal of Multidisciplinary Research (IJMR) - Peer Reviewed Journal Volume: 7 | Issue: 5 | May 2021|| Journal DOI: 10.36713/epra2013 || SJIF Impact Factor 2021: 8.047 || ISI Value: 1.188

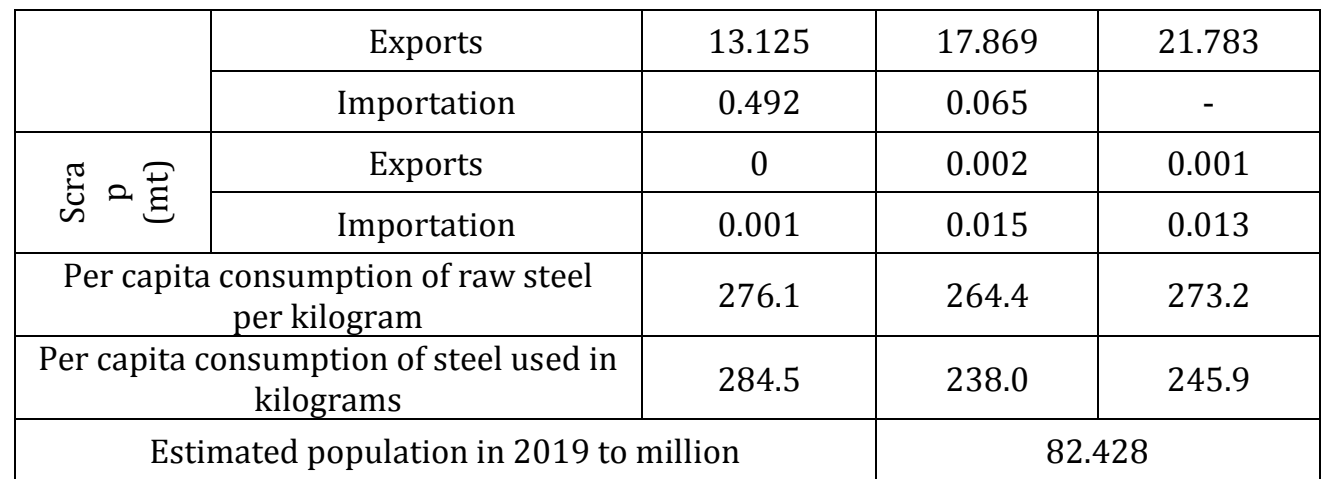

\section{2-1-4. Iron and steel Industry of Pakistan}

Increasing demand for steel for construction will triple overall demand for steel. The costs of housing demand are higher due to the high level of income, which with the development of infrastructure, the demand for construction, including steel, will continue to improve[11].

- Vision

Pakistan's vision for a strong, comprehensive iron and steel industry is attractive for investment and motivated for the sustainable growth of the private sector mining industry that significantly contributes to economic development[12].

- Mission

The Ministry of Petroleum and Natural Resources has responsible for establishing policy structures, providing policy guidance in the States, and coordinating the development of Pakistan's mines with the attraction and retention of private sector investment in the steel industry[12].

Pakistan's iron and steel industry has experienced severe fluctuations this decade. But still, its crude steel output measure had been upward with slightly deference. Due to its ups and downs which had in the iron and steel industry, it has not provided complete and accurate figures to the World Steel Association. In this part of the study, the volatility and fluctuations of Pakistan's iron and steel industry from 2015 to 2017 is summarized in Table 4.

Table 4: Comparison of Performance of Pakistani Iron and Steel Industry between 2015 to 2017 [2].

\begin{tabular}{|c|c|c|c|c|}
\hline \multicolumn{2}{|c|}{ Indicators } & 2015 & 2016 & 2017 \\
\hline \multicolumn{2}{|c|}{ Crude steel production (mt) } & 2.892 & 3.553 & 4.966 \\
\hline \multirow{4}{*}{ 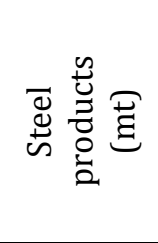 } & Manufacturing & - & - & - \\
\hline & Demand & 8.2 & 10.4 & 11.8 \\
\hline & Importation & 6.8 & 8.7 & 7.8 \\
\hline & Exports & 1.2 & 1.4 & 0.7 \\
\hline \multirow{3}{*}{ 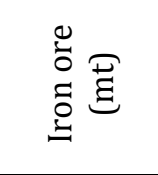 } & Manufacturing & - & - & - \\
\hline & Exports & - & - & - \\
\hline & Importation & - & - & - \\
\hline \multirow{2}{*}{$\underset{\tilde{\omega}}{\frac{\pi}{\vec{\Xi}}}$} & Exports & - & - & - \\
\hline & Importation & 2.119 & 2.388 & 2.830 \\
\hline \multicolumn{2}{|c|}{$\begin{array}{c}\text { Per capita consumption of raw steel } \\
\text { per kilogram }\end{array}$} & 34.1 & 42.0 & 45.7 \\
\hline \multicolumn{2}{|c|}{$\begin{array}{c}\text { Per capita consumption of steel used in } \\
\text { kilograms }\end{array}$} & 32.1 & 39.5 & 43.0 \\
\hline \multicolumn{3}{|c|}{ Estimated population in 2019 to million } & \multicolumn{2}{|c|}{204.578} \\
\hline
\end{tabular}




\section{2-2. A Look at the Performance of the Iron and Steel Industry in Afghanistan}

One of the most influential criteria in dividing different countries in the world is the average per capita consumption steel of them. In 2004, the World Bank, in a report, divided the world countries into four groups in terms of steel consumption per capita:

1. Countries are with a maximum per capita income of $735 \$$ with an average steel consumption of about $15 \mathrm{~kg}$. These countries are in this group include India, Indonesia, Bangladesh, Azerbaijan, Pakistan, Sudan and Kenya. Since Afghanistan is one of the developing countries and terms of economically is poor and also doesn't have good condition, unemployment level and poverty are high, and with an average per capita income is less than $528 \$$ and stand including part of the countries in this group, Per capita ofsteel consumption is about $15 \mathrm{~kg}$ in Afghanistan. But with attention of the economic growth measure, population growth and the level of development, the per capita consumption of steel is estimated to be $25 \mathrm{~kg}$ for next calculation[13].

2. Countries with a per capita income of between $736 \$$ and $2935 \$$ with an average steel consumption is about $115 \mathrm{~kg}$. Algeria, Bulgaria, China, Turkey and Russia are present in this category[13].

3. Countries with a per capita income of $2936 \$$ to $9075 \$$ with an average per capita consumption of steel in these countries are about $254 \mathrm{~kg}$. Many countries are such as Argentina, Hungary, Mexico, Venezuela, Saudi Arabia, Lebanon and Malaysia fall into this category. Countries with a per capita income above $9075 \$$ with an average steel consumption is about $514 \mathrm{~kg}$. Industrialized and developed countries fall into this category[13].

With attention of the economic growth rate and population growth, Afghanistan's steel consumption per capita is based on three scenarios (realistic, optimistic and pessimistic) and the required steel demand estimate by the horizon of 2030. According to the Afghan Census Bureau, population growth in 2018 has reached 2.3 percentAnd economic growth is 2.5 percent. On the other hand, the average per capita income in Afghanistan in 2018 has defined at less than 528 \$ in per[14]. Then, according to the economic growth of per capita income up to the horizon of 2030, it has calculated in different scenarios and has presented in Table 5.

Table 5: Estimates of per capita income in terms of economic growth to 2030 horizon in different scenarios per dollarper year

\begin{tabular}{|c|c|c|c|c|}
\hline \multirow{2}{*}{$\begin{array}{c}\text { Average per } \\
\text { capita income } \\
\text { (dollars per } \\
\text { year) }\end{array}$} & \multicolumn{3}{|c|}{ Per capita income in different scenarios up to } & \multirow{2}{*}{ 2030 horizon } \\
\cline { 2 - 4 } & Pessimistic & Optimistic & Realistic & \multirow{2}{*}{ Year } \\
\cline { 2 - 4 } & 0.015 & 0.030 & 0.025 & 2018 \\
\hline 541 & 536 & 544 & 541 & 2019 \\
\hline 554 & 544 & 560 & 555 & 2020 \\
\hline 567 & 552 & 577 & 569 & 2021 \\
\hline 581 & 560 & 594 & 583 & 2022 \\
\hline 595 & 569 & 612 & 597 & 2023 \\
\hline 612 & 577 & 630 & 612 & 2024 \\
\hline 624 & 586 & 649 & 628 & 2025 \\
\hline 639 & 595 & 669 & 643 & 2026 \\
\hline 655 & 604 & 689 & 695 & 2027 \\
\hline 671 & 613 & 709 & 676 & 2028 \\
\hline 687 & 622 & 731 & 693 & 2029 \\
\hline 704 & 631 & 753 & 710 & 2030 \\
\hline 619 & $\mathbf{5 8 2}$ & $\mathbf{6 4 3}$ & $\mathbf{6 1 2}$ & Average \\
\hline
\end{tabular}

With attention of per capita income in different years and the World Bank's approach, per capita incometotaly in all scenarios is less than $735 \$$ by the horizon of 2030, and in the other hand steel consumption per capita is 
less than $15 \mathrm{~kg}$. Therefore, the per capita consumption of steel to attention of the important effective ingredientshas assumed to be $25 \mathrm{~kg}$ in per year, as shown in Table 6 .

Table 6: Estimates of per capita steel consumption in different scenarios up to 2030 horizon

\begin{tabular}{|c|c|c|c|}
\hline \multicolumn{2}{|c|}{$\begin{array}{c}\text { Per capita consumption of steel in different } \\
\text { scenarios per kg per year }\end{array}$} & Indices \\
\hline Pessimistic & Optimistic & Realistic & \\
\hline 582 & 643 & 622 & $\begin{array}{c}\text { Average per capita income in dollars per } \\
\text { year }\end{array}$ \\
\hline \multicolumn{3}{|c|}{25} & $\begin{array}{c}\text { Forecast average consumption per } \\
\text { capita by 2030 horizon in kg }\end{array}$ \\
\hline
\end{tabular}

\section{2-3. Define and formulate a vision and mission}

Definition of Vision and Mission for Development Plans in Afghanistan's Iron and Steel Industry has done According to studies, reviews of selected countries' bylaws and interviews with experts.

\section{2-3.1. Vision}

Sustainable growth of mining, attractive for investment, active in global value chain of minerals, employment with environmental protection will be acceptable vision.

\section{2-3.2. Mission}

Trace and discovery of minerals, The processing of extraction minerals and creation of revenue, Attracting Private Investment, Developing the Processing Industry and Supplying Iron and Steel Raw Materials with Employment will be part of mission.

\section{2-4. Identifying Effective Factors on codification in Development Strategies for Afghanistan Based on Neighborhood Policy Analysis}

In order to formulate development strategies in the field of iron and steel industries in Afghanistan, first, according to the current situation in Afghanistan and the factors affecting the iron and steel industries in neighboring countries, threats and opportunities have been received and include Tables 7 and 8 . then, by arranging and distributing questionnaires and interviewing experts, the factors that have the most impact on the definition and formulation of strategies are obtained and the results are listed in Table 9.

Table 7: Afghanistan's Threatsin Iron and Steel Industry Development Plans onAccordingto theStrenthsNeighbors' countries

\begin{tabular}{|c|c|c|c|}
\hline \multirow{2}{*}{ Afghanistan threats } & \multicolumn{3}{|c|}{ Strengths of countries } \\
\hline & Pakistan & Iran & China \\
\hline $\begin{array}{l}\text { - Highness investment risk } \\
\text { despite the groups of terrorist } \\
\text { and political tensions } \\
\text { - access to global The difficult } \\
\text { markets for the lack of blue } \\
\text { boundary } \\
\text { - The existence of industrial } \\
\text { rivals in the region } \\
\text { - The lack of energy enough to } \\
\text { power and gas } \\
\text { - The lack of investment in } \\
\text { private and government } \\
\text { sections }\end{array}$ & $\begin{array}{l}\text { - The probability of } \\
\text { increasing domestic } \\
\text { demand by starting } \\
\text { underlying projects } \\
\text { - Resume } \\
\text { activityfactory ( } \\
\text { PSMCL) } \\
\text { - Access to regional } \\
\text { markets and the world }\end{array}$ & $\begin{array}{l}\text { - The specialized } \\
\text { organizations and } \\
\text { associations } \\
\text { - The potential of } \\
\text { potential ability to } \\
\text { exploit exploration } \\
\text { technologies, } \\
\text { processing and } \\
\text { production in the } \\
\text { mineral industry } \\
\text { - Existence of } \\
\text { specialist forces } \\
\text { - Existential Great } \\
\text { Festivals }\end{array}$ & $\begin{array}{l}\text { - Competitive } \\
\text { product production } \\
\text { checked force } \\
\text { - Having more } \\
\text { expensive and } \\
\text { - Impressive growth } \\
\text { of industries } \\
\text { - More investment in } \\
\text { science and } \\
\text { technology } \\
\text { - The existence of full } \\
\text { geological } \\
\text { information from } \\
\text { resources }\end{array}$ \\
\hline
\end{tabular}


Table 8: Afghanistan's Opportunities in Iron and Steel Industry Development Planson According to the Weaknesses Neighbors'countries

\begin{tabular}{|c|c|c|c|}
\hline \multirow{2}{*}{ AfghanistanOpportunities } & \multicolumn{3}{|c|}{ The weaknesses of countries } \\
\hline & Pakistan & Iran & China \\
\hline $\begin{array}{l}\text { - World support from different } \\
\text { sections } \\
\text { - Geographic location suitable } \\
\text { for access to the market area } \\
\text { - The desire to external } \\
\text { investment in different parts of } \\
\text { Afghanistan } \\
\text { - Boundary with China, the } \\
\text { largest iron ore importer } \\
\text { - Increasing the internal demand } \\
\text { of iron and Palwald }\end{array}$ & $\begin{array}{l}\text { - of sufficient The lack } \\
\text { mineral resources of } \\
\text { iron ore } \\
\text { - The lack of coal coke } \\
\text { resources } \\
\text { - The lack of sufficient } \\
\text { infrastructure } \\
\text { - Reduce domestic and } \\
\text { external investment } \\
\text { - Weakness in } \\
\text { government policies }\end{array}$ & $\begin{array}{l}\text { - Inadequate Specialist } \\
\text { Force and Equipment } \\
\text { - Inadequate Paying to } \\
\text { Optimal Management } \\
\text { of Minerals } \\
\text { Production } \\
\text { - Many mineral } \\
\text { schemes, especially } \\
\text { large mines } \\
\text { - Low productivity in } \\
\text { the mining } \\
\text { department }\end{array}$ & $\begin{array}{l}\text { - Dependence on iron } \\
\text { ore imports } \\
\text { - Not launching global } \\
\text { standards in the } \\
\text { mineral industry } \\
\text { - The probability of } \\
\text { shortage of } \\
\text { workforce in the } \\
\text { future }\end{array}$ \\
\hline
\end{tabular}

Table 9:Affecting Internal and environmental factors the definition and formulation of development strategies

\begin{tabular}{|c|c|c|c|}
\hline $\begin{array}{l}\text { Total } \\
\text { Score }\end{array}$ & Factors & $\begin{array}{c}\text { Total } \\
\text { score }\end{array}$ & Factors \\
\hline \multicolumn{2}{|r|}{ Strengths } & \multicolumn{2}{|r|}{ weaknesses } \\
\hline 93 & $\begin{array}{c}\text { The existence of rich and small mineral } \\
\text { resources }\end{array}$ & 90 & Lack of the Geological Informationupdate \\
\hline 89 & Cheap force & 87 & $\begin{array}{c}\text { The shortages in law and government } \\
\text { rules }\end{array}$ \\
\hline 88 & Existence of geological base information & 83 & $\begin{array}{l}\text { The lack of adequate infrastructure } \\
\text { existence }\end{array}$ \\
\hline 85 & $\begin{array}{l}\text { The existence of abundant water } \\
\text { resources }\end{array}$ & 78 & weaknesses in government policy making \\
\hline 76 & Having enough resid coal resources & & \\
\hline \multicolumn{2}{|r|}{ Opportunities } & \multicolumn{2}{|r|}{ Threats } \\
\hline 97 & Global support from different sectors & 89 & $\begin{array}{l}\text { High risk investment despite ofthe terrorist } \\
\text { groups and political tensions difficult }\end{array}$ \\
\hline 94 & $\begin{array}{l}\text { The adequate geological location for } \\
\text { access to the region markets }\end{array}$ & 85 & $\begin{array}{l}\text { Difficult Access to the global markets } \\
\text { than the lack of blue border }\end{array}$ \\
\hline 88 & $\begin{array}{l}\text { A tendency to foreign investment in } \\
\text { different parts of Afghanistan }\end{array}$ & 76 & $\begin{array}{c}\text { The existence of industrial rivals in the } \\
\text { region }\end{array}$ \\
\hline 79 & $\begin{array}{l}\text { Having Boundary with China, the largest } \\
\text { iron ore importer }\end{array}$ & 71 & Lack of power and gas energy \\
\hline 77 & $\begin{array}{l}\text { Increasing the internal demand to the } \\
\text { iron and steel }\end{array}$ & 65 & $\begin{array}{l}\text { Lack of investment in private and } \\
\text { government sectors }\end{array}$ \\
\hline
\end{tabular}

\section{RESULTS AND DISCUSSION}

\section{3-1. Define and formulate development strategies by SWOT technique}

After identifying the effective internal factors (strengths and weaknesses) and environmental factors (opportunities and threats) that have the greatest impact on Afghanistan's iron and steel industry, Using the SWOT technique, Afghanistan's iron and steel industry development strategies are defined in four forms (offensive, competitive, conservative and defensive) and eight categories, including Table 10. 
EPRA International Journal of Multidisciplinary Research (IJMR) - Peer Reviewed Journal Volume: 7 | Issue: 5 | May 2021|| Journal DOI: 10.36713/epra2013 || SJIF Impact Factor 2021: 8.047 || ISI Value: 1.188

Table 10:SWOT matrix and predicted development strategies in the field of iron and steel industry in Afghanistan

\begin{tabular}{|c|c|c|c|c|}
\hline $\begin{array}{c}\text { Description of the } \\
\text { strategies }\end{array}$ & $\begin{array}{c}\text { Type of } \\
\text { strategies }\end{array}$ & Description of the factors & Factors & Strategies \\
\hline \multirow{4}{*}{$\begin{array}{l}\text { Construction and } \\
\text { development of iron } \\
\text { ore processingfatories } \\
\text { and steel production }\end{array}$} & \multirow{4}{*}{ S } & $\begin{array}{l}\text { The existence of abundant water } \\
\text { resources }\end{array}$ & $\mathrm{S}_{4}$ & \multirow{4}{*}{ Strategy1 } \\
\hline & & $\begin{array}{l}\text { Adequate geographical location for access } \\
\text { to the rigion market }\end{array}$ & $\mathrm{O}_{2}$ & \\
\hline & & $\begin{array}{l}\text { A tendency to foreign investment in } \\
\text { different parts of Afghanistan }\end{array}$ & $\mathrm{O}_{3}$ & \\
\hline & & $\begin{array}{l}\text { Increasing the internal demand for iron } \\
\text { and steel }\end{array}$ & $\mathrm{O}_{5}$ & \\
\hline \multirow{4}{*}{$\begin{array}{l}\text { Investing in the field } \\
\text { of mineral deposits } \\
\text { and supply internal } \\
\text { and external needs }\end{array}$} & \multirow{4}{*}{$\mathrm{SO}_{2}$} & $\begin{array}{c}\text { The existence of rich and small mineral } \\
\text { resources }\end{array}$ & $\mathrm{S}_{1}$ & \multirow{4}{*}{ Strategy2 } \\
\hline & & Global support from different sectors & $\mathrm{O}_{1}$ & \\
\hline & & $\begin{array}{l}\text { A tendency to foreign investment in } \\
\text { different parts of Afghanistan }\end{array}$ & $\mathrm{O}_{3}$ & \\
\hline & & $\begin{array}{l}\text { HavingBoundary with China, the largest } \\
\text { iron ore importer }\end{array}$ & $\mathrm{O}_{4}$ & \\
\hline \multirow{3}{*}{$\begin{array}{l}\text { Exploiting ofsmall } \\
\text { mines and supply the } \\
\text { internal needs iron } \\
\text { ore and market area }\end{array}$} & \multirow{3}{*}{$\mathrm{SO}_{3}$} & $\begin{array}{c}\text { The existence of rich and small mineral } \\
\text { resources }\end{array}$ & $\mathrm{S}_{1}$ & \multirow{3}{*}{ Strategy3 } \\
\hline & & The presence of geological bases & $\mathrm{S}_{3}$ & \\
\hline & & $\begin{array}{l}\text { Adequate geographical location for access } \\
\text { to the rigion market }\end{array}$ & $\mathrm{O}_{2}$ & \\
\hline \multirow{3}{*}{$\begin{array}{l}\text { Compilation of } \\
\text { appropriate rules for } \\
\text { exploration and } \\
\text { standardization of } \\
\text { mining law with } \\
\text { global support }\end{array}$} & \multirow{3}{*}{$\mathrm{WO}_{1}$} & Lack of the Geological Informationupdate & $\mathrm{W}_{1}$ & \multirow{3}{*}{ Strategy 4} \\
\hline & & $\begin{array}{c}\text { Shortages in the law and regulations of } \\
\text { the government }\end{array}$ & $\mathrm{W}_{2}$ & \\
\hline & & Global support from different sectors & $\mathrm{O}_{1}$ & \\
\hline \multirow{3}{*}{$\begin{array}{l}\text { Government support } \\
\text { from foreign } \\
\text { investment in the } \\
\text { development of } \\
\text { infrastructure } \\
\end{array}$} & \multirow{3}{*}{$\mathrm{WO}_{2}$} & $\begin{array}{l}\text { The lack of sufficient infrastructure } \\
\text { existence }\end{array}$ & $\mathrm{W}_{3}$ & \multirow{3}{*}{ Strategy 5} \\
\hline & & Weakness in government policy making & $\mathrm{W}_{4}$ & \\
\hline & & Global support from different sectors & $\mathrm{O}_{1}$ & \\
\hline \multirow{3}{*}{$\begin{array}{c}\text { Improving human } \\
\text { resources and } \\
\text { development of } \\
\text { manufacturing } \\
\text { industries } \\
\end{array}$} & \multirow{3}{*}{$\mathrm{ST}_{1}$} & Cheap curry force & $\mathrm{S}_{2}$ & \multirow{3}{*}{ Strategy6 } \\
\hline & & Having enough resid coal resources & $\mathrm{S}_{5}$ & \\
\hline & & $\begin{array}{c}\text { The existence of industrial rivals in the } \\
\text { region }\end{array}$ & $\mathrm{T}_{3}$ & \\
\hline \multirow{4}{*}{$\begin{array}{l}\text { Use of natural and } \\
\text { mineral resources with } \\
\text { the support of } \\
\text { investment to provide } \\
\text { energy needed }\end{array}$} & \multirow{4}{*}{$\mathrm{ST}_{2}$} & resources The existence of abundant water & $\mathrm{S}_{4}$ & \multirow{4}{*}{ Strategy7 } \\
\hline & & Having enough resid coal resources & $\mathrm{S}_{5}$ & \\
\hline & & Lack of enough power and gas energy & $\mathrm{T}_{4}$ & \\
\hline & & $\begin{array}{c}\text { Lack of investment in private and } \\
\text { government sectors }\end{array}$ & $\mathrm{T}_{5}$ & \\
\hline \multirow{4}{*}{$\begin{array}{l}\text { The planning of } \\
\text { geological } \\
\text { development and } \\
\text { infrastructure } \\
\text { development and } \\
\text { investment support to } \\
\text { access the global } \\
\text { markets }\end{array}$} & \multirow{4}{*}{$\mathrm{WT}_{1}$} & Lack of the Geological Informationupdate & $\mathrm{W}_{1}$ & \multirow{4}{*}{ Strategy8 } \\
\hline & & The lack of sufficient infrastructure & $\mathrm{W}_{3}$ & \\
\hline & & $\begin{array}{l}\text { despite Highness investment risk ofthe } \\
\text { terrorist groups and political tensions }\end{array}$ & $\mathrm{T}_{1}$ & \\
\hline & & $\begin{array}{l}\text { Difficult Access to the global markets } \\
\text { than the lack of blue border }\end{array}$ & $\mathrm{T}_{2}$ & \\
\hline
\end{tabular}


According to the research conducted in the field of internal and environmental factors on the analysis of the strategy of Afghanistan Iron and Steel Industries, Eight sets of macro strategies have been identified for Afghanistan's iron and steel industry development plans, Which are as follows:

1. Construction and Development of Iron Ore Processing Plant and Steel Production $\left(\mathrm{SO}_{1}\right)$

2. Investing in field of Mining Resources extraction and Supplying Internal and External Needs $\left(\mathrm{SO}_{2}\right)$

3. Exploitation of Small Mines and Supply of the needs Iron Ore Required Within or internal and Market Area $\left(\mathrm{SO}_{3}\right)$

4. Codification of Appropriate Laws to Explore and Standardize Mining Law with Global Support $\left(\mathrm{WO}_{1}\right)$

5. Government Support from Foreign Investment in Infrastructure Development $\left(\mathrm{WO}_{2}\right)$

6. Promotion of Human Resources and Development of Product Manufacturing Industries $\left(\mathrm{ST}_{1}\right)$

7. Use of natural and mineral resources with the support of investment to supply needed energy $\left(\mathrm{ST}_{2}\right)$

8. Design the Developing Geological programs and Infrastructure Development Plans and Supporting from Investment to Access World Markets $\left(\mathrm{WT}_{1}\right)$

\section{3-2. Ranking Strategies}

In order to rank development strategies, first, internal and environmental factors affecting the definition and formulation of strategies are selected as criteria and defined strategies as candidate options. The weights of the criteria are calculated using the Entropy Shannon method and the results are entered into the Promethee method for ranking. Finally, the options (strategies) are ranked according to the prices of net flows

\section{3-2-1. Computing of criteria weights using the Entropy Shannon method}

Shannon entropy method in multi-criteria decision Issues and especially multi-criteria decision Issues, to have and know the relative weights of existing indicators, is an effective method in the Issues solving process[15]. In this case, according to the steps of the method, first, quantitative numbers are defined to recognize the importance of the criteria relative to the option, which includes Table 11. Then, the order and distribution of questionnaires and interviews with experts were performed, based on the results of which the decision matrix was formed according to Equation 1 and includes Table 1 of Appendix 1.In the decision matrix, columns are selected as criteria and rows are selected as options.Example $\mathrm{X}_{12}$ shows the score of the first option compared to the second criterion.Then the decision matrix is normalized based on Equation 2 and the results are listed in Table 2 of Appendix 1.

$$
\begin{aligned}
& X=\left[X_{i j}\right]_{n \times m}=\left[\begin{array}{cccc}
X_{11} & X_{12} & \ldots & X_{1 m} \\
X_{21} & X_{22} & \ldots & X_{2 m} \\
\vdots & \vdots & \vdots & \vdots \\
X_{n 1} & X_{n 2} & \ldots & X_{n m}
\end{array}\right] \\
& P_{i j}=\frac{X_{i j}}{\sum_{i=1}^{n} X_{i j}}
\end{aligned}
$$

The entropy of each criterion $(\mathrm{Ej})$ is calculated based on Equation 3, and $\mathrm{k}$ is taken as the constant value of $\mathrm{Ej}$ for all criteria from Equation 4.

$$
\begin{aligned}
& E_{j}=-K \sum_{i=1}^{m} P_{i j} \times L_{n} P_{i j} \quad i=1,2, \ldots, m \\
& k=\frac{1}{\operatorname{Ln}\left(n_{i}\right)}
\end{aligned}
$$

The degree of deviation of each criterion (dj) is calculated based on Equation 5 and indicates how much useful information the relevant index provides to the decision maker. As close as the measured values of the index (dj), Indicates that competing options are not significantly different from each other in terms of that index.

$$
d_{j}=1-E_{j}
$$

Next, the normalized weight of the criteria $(\mathrm{Wj})$ is calculated based on Equation 6, the results of which are included in Table 3 of Appendix 1. Finally, the final weight of the criteria $\left(W_{j}^{0}\right)$ is calculated based on the 
degree of deviation and the relative weight of the criteria based on Equation 7, and the results are included in Table 12. In this relation, $\lambda_{j}$ is a specific weight that is predefined for each criterion.

$$
\begin{aligned}
& W_{j}=\frac{d_{j}}{\sum_{i=1}^{m} d_{j}} \\
& W^{0}=\frac{\lambda_{j} W_{j}}{\sum_{j=1}^{m} \lambda_{j} W_{j}}
\end{aligned}
$$

Table 11: Quantitative Numbers to Evaluate the Importance of Criteria to Options

\begin{tabular}{|c|c|}
\hline The degree of importance & Verbal phrases \\
\hline 0.00 & Very much nonsignificant \\
\hline 0.50 & Relatively low importance \\
\hline 1.00 & significance The same \\
\hline 1.50 & Relativelypreference \\
\hline 2.00 & Very muchpreference \\
\hline
\end{tabular}

Table 12: Final Weights of Criteria

\begin{tabular}{|c|c|c|c|c|c|c|c|c|c|c|}
\hline Criteria & $\mathbf{S}_{\mathbf{1}}$ & $\mathbf{S}_{\mathbf{2}}$ & $\mathbf{S}_{\mathbf{3}}$ & $\mathbf{S}_{\mathbf{4}}$ & $\mathbf{S}_{\mathbf{5}}$ & $\mathbf{W}_{\mathbf{1}}$ & $\mathbf{W}_{\mathbf{2}}$ & $\mathbf{W}_{\mathbf{3}}$ & \multicolumn{2}{|c|}{$\mathbf{W}_{\mathbf{4}}$} \\
\hline $\begin{array}{c}\text { Ultimate } \\
\text { weight } \\
\text { of } \\
\text { criteria }\end{array}$ & 0.04 & 0.06 & 0.02 & 0.14 & 0.11 & 0.09 & 0.04 & 0.03 & 0.03 \\
\hline Criteria & $\mathbf{0}_{\mathbf{1}}$ & $\mathbf{0}_{\mathbf{2}}$ & $\mathbf{0}_{\mathbf{3}}$ & $\mathbf{0}_{\mathbf{4}}$ & $\mathbf{0}_{\mathbf{5}}$ & $\mathbf{T}_{\mathbf{1}}$ & $\mathbf{T}_{\mathbf{2}}$ & $\mathbf{T}_{\mathbf{3}}$ & $\mathbf{T}_{\mathbf{4}}$ & $\mathbf{T}_{\mathbf{5}}$ \\
\hline $\begin{array}{c}\text { Ultimate } \\
\text { weight } \\
\text { of } \\
\text { criteria }\end{array}$ & 0.03 & 0.13 & 0.03 & 0.06 & 0.06 & 0.01 & 0.07 & 0.02 & 0.04 & 0.02 \\
\hline
\end{tabular}

\section{3-2-2. Prioritizing options (strategies) with using the Promethee method}

This method is one of the multi-criteria decision making methods that aims to rank the options[16]. According to the steps of the perimeter method, first the questionnaires were arranged and distributed and interviews were conducted with experts. In this case, the experts, considering the effect of factors on the strategies and the type of function, which is expressed in Figure 2, Express the fluctuation of scores in the range of zero to p. If the difference is greater than $\mathrm{p}$, the first option has a full score. According to the results of the questionnaires, the decision matrix is based on Equation 1, which includes Table 4, Appendix 1.

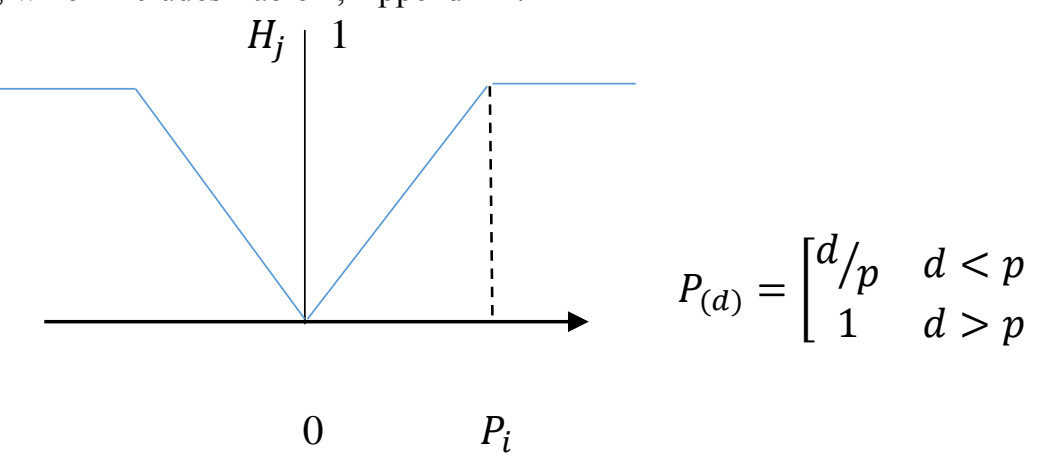

Figure 2: Preference function[16]. 
Indifference threshold $(q)$ and preference $(p)$ The criteria are determined according to the type of preference function and options. The difference $\left(d_{j}\right)$ and the preference function $\left(p_{j}\right)$ of each option over the other options are based on relationships 8 and 9 according to the criteria.

$$
\begin{aligned}
& d_{j(a, b)}=f_{j(a)}-f_{j(b)} \\
& P_{j(a, b)}=\frac{p}{d_{j(a, b)}}
\end{aligned}
$$

The degree of preference $\left(\pi_{j}\right)$ of each option over the other options is calculated based on the final weights of the criteria using Equation 10.

$$
\pi_{j(a, b)}=\sum_{j=1}^{k} P_{j(a, b)} \times w_{j}
$$

The positivepreference flow $\left(Q_{j}^{+}\right)$and negativepreference flow $\left(Q_{j}^{-}\right)$of each option are calculated based on Equations 11 and 12, Finally, according to the positive and negative preferenceflows, the netpreference flow $\left(Q_{(a)}\right)$ of each option is received based on Equation 13, based on which the options are ranked and the results are listed in Table 13.

$$
\begin{aligned}
& Q_{j}^{+}=\frac{1}{(n-1) \sum \pi_{(a, x)}} \\
& Q_{j}^{-}=\frac{1}{(n-1) \sum \pi_{(x, a)}} \\
& Q_{(a)}=Q_{(a)}^{+}-Q_{(a)}^{-}
\end{aligned}
$$

Table 13: Ranking Strategies based on Net preference flow

\begin{tabular}{|c|c|c|c|c|}
\hline Options & $\begin{array}{c}\text { Positivepreference } \\
\text { flow }\end{array}$ & $\begin{array}{c}\text { Negativepreference } \\
\text { flow }\end{array}$ & $\begin{array}{c}\text { Net preference } \\
\text { flow }\end{array}$ & Ranking \\
\hline $\mathrm{SO}_{1}$ & 0.19 & 0.06 & 0.13 & 3 \\
\hline $\mathrm{SO}_{2}$ & 0.07 & 0.07 & 0.00 & 8 \\
\hline $\mathrm{SO}_{3}$ & 0.17 & 0.04 & 0.13 & 2 \\
\hline $\mathrm{WO}_{1}$ & 0.07 & 0.06 & 0.01 & 7 \\
\hline $\mathrm{WO}_{2}$ & 0.07 & 0.03 & 0.04 & 4 \\
\hline $\mathrm{ST}_{1}$ & 0.09 & 0.06 & 0.03 & 5 \\
\hline $\mathrm{ST}_{2}$ & 0.18 & 0.04 & 0.14 & 1 \\
\hline $\mathrm{WT}_{1}$ & 0.04 & 0.01 & 0.03 & 6 \\
\hline
\end{tabular}

\section{CONCLUSION}

According to the studies conducted in the field of analysis of Afghanistan iron and steel industry and the use of internal and environmental factors affecting strategic analysis, The results and summary of this part of the research include the definition and formulation of eight categories of macro strategies for the quantitative and qualitative development of the iron and steel industry in Afghanistan, which are as follows:

1. Construction and Development of Iron Ore Processing Plants and development of the procreation iron stone factories and Steel Production $\left(\mathrm{SO}_{1}\right)$

2. Investing in field of the Mining Resources extraction and Supplying of the Internal and External Needs $\left(\mathrm{SO}_{2}\right)$

3. Exploitation of Small Mines and Supply of Iron Ore needs Required Within and Market Area $\left(\mathrm{SO}_{3}\right)$

4. Codification of the Appropriate Laws to Explore and Standardize Mining Law with Global Support $\left(\mathrm{WO}_{1}\right)$

5. Government Support from Foreign Investment in Infrastructure Development $\left(\mathrm{WO}_{2}\right)$

6. Promotion of Human Resources and Development of Product Manufacturing Industries $\left(\mathrm{ST}_{1}\right)$

7. The Use of natural and mineral resources with the support of investment to supply needed energy $\left(\mathrm{ST}_{2}\right)$ 
8. Design the Developing Geological programs and Infrastructure Development Plans and Supporting from Investment to Access to the World Markets $\left(\mathrm{WT}_{1}\right)$

Also according to the figures obtained from the calculations of the Promethee method,The options are ranked as a result of which the $\mathrm{ST}_{2}$ strategy is the priority of the development plans and the $\mathrm{SO}_{2}$ strategy is at the end of the development plans. And the rest of the strategies have taken different positions according to the amount of their Net preference flow.

\section{REFERENCES}

1. K. Fttahi, Iran and world steel industry analysis, first, Moblghan, Tehran, 2012. doi:1871470.

2. WSA, World Steel Association, World Steel Assoc. (2018). http://www.worldsteel.org/publicationfiles/SSY 2019.pdf. (accessed March 12, 2019).

3. T.W. Chricio, P G and Moran, Topographic and hydrographic GIS dataset for 2010 Afghanistan geology survey and USGS Minerals project, Kabul, 2011. https://pubs.er.usgs.gov/publication/ds624.

4. Ministry of Industry and Commerce., Annual report, Kabul, 2018. https://moci.gov.af/en.

5. M. Jin, F. Li, The recent development of accounting education in China, China Iron Steel Assoc. (2002) 1-24.

6. Decision Conseill Etudes, Vision, Mission and Strategy, Paris, 2013. https://www.entreprises.gouv.fr.

7. J. Roy, S. Roy, Indian steel industry, (2013).

8. EY, Indian steel: strategy to ambition, 2015. https://www.ey.com.

9. J. Tehrani, Iranian Iron \& Steel Industry Update, Tehran, 2015. https://www.metalbulletin.com.

10. FIECO, Iran 2025 Steel Vision, 2016.

11. M.S. Hussain, IMPORTANCE OF IRON AND STEEL INDUSTRIES, IN THE BACKDROP OF PAKISTAN STEEL, Karachi, 2019. https://www.researchgate.net.

12. Ministry of Petroleum and Natural Resources, NATIONAL MINERAL POLICY, Islamabad, 2013. https://mnm.punjab.gov.pk.

13. World Bank, Ranking World Countries from the Level of Development According to the per Capita Consumption of Steel, Washington, 2004. https://openknowledge.worldbank.org.

14. National Statistics Center of Afghanistan, Population Estimate 2015, Kabul, 2016. https://washdata.org.

15. A. Ijadi Maghsoodi, G. Abouhamzeh, M. Khalilzadeh, E.K. Zavadskas, Ranking and selecting the best performance appraisal method using the MULTIMOORA approach integrated Shannon's entropy, Front. Bus. Res. China. 12 (2018) 2. doi:10.1186/s11782-017-0022-6.

16. A. Abdullah, L., Chan, W., \& Afshari, Application of PROMETHEE method for green supplier selection: a comparative result based on preference functions, J. Ind. Eng. Int. (2019) 271-285. https://doi.org/10.1007/s40092-018-0289-z(0123456789().,-volV)(0123456789(). ,- volV). 
Appendix 1:

Table 1: Decision Matrix

\begin{tabular}{|c|c|c|c|c|c|c|c|c|c|c|c|c|c|c|c|c|c|c|c|}
\hline $\begin{array}{c}\text { Criteria } \\
/ / \\
\text { Options }\end{array}$ & 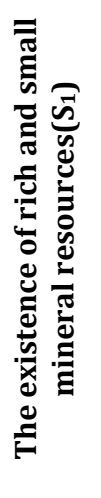 & 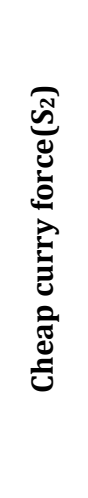 & 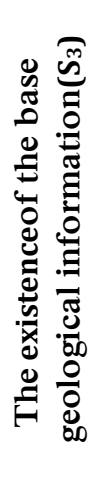 & 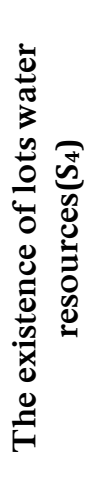 & 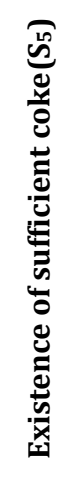 & 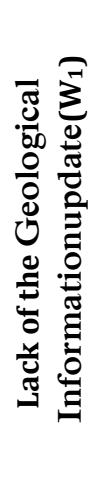 & 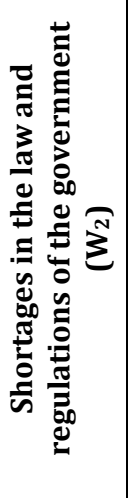 & 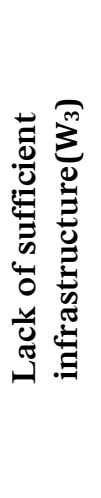 & 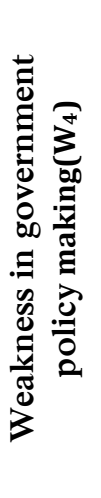 & 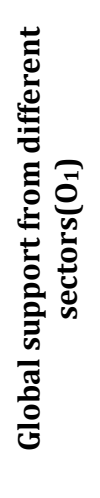 & 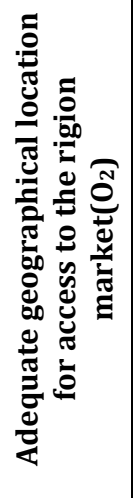 & 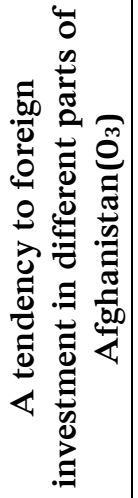 & 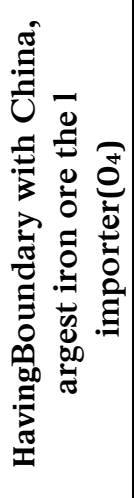 & 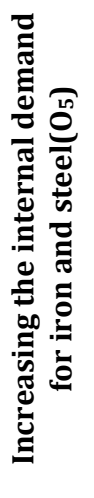 & 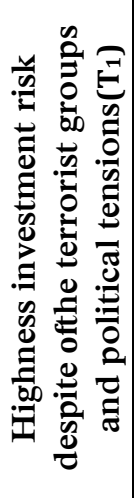 & 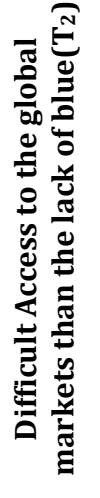 & 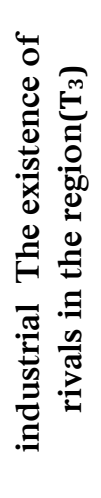 & 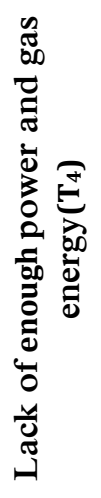 & 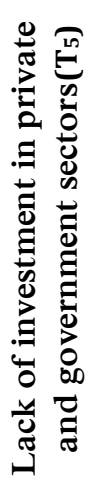 \\
\hline $\mathrm{SO}_{1}$ & 1.28 & 0.94 & 1.28 & 2.00 & 2.00 & 0.66 & 0.57 & 1.38 & 0.66 & 1.28 & 2.00 & 2.00 & 1.08 & 2.00 & 0.66 & 0.57 & 1.50 & 1.28 & 0.76 \\
\hline $\mathrm{SO}_{2}$ & 2.00 & 0.50 & 1.08 & 0.57 & 0.57 & 1.50 & 1.00 & 1.08 & 0.50 & 2.00 & 0.50 & 2.00 & 2.00 & 0.50 & 1.50 & 0.76 & 1.18 & 1.08 & 1.38 \\
\hline $\mathrm{SO}_{3}$ & 2.00 & 1.28 & 2.00 & 0.57 & 0.66 & 1.00 & 0.50 & 0.50 & 1.00 & 0.50 & 2.00 & 1.00 & 0.50 & 1.00 & 1.00 & 0.50 & 1.08 & 1.00 & 1.50 \\
\hline $\mathrm{WO}_{1}$ & 0.94 & 0.76 & 0.94 & 0.66 & 0.50 & 2.00 & 2.00 & 1.00 & 1.50 & 2.00 & 0.50 & 0.50 & 0.66 & 1.00 & 1.50 & 0.66 & 1.50 & 0.50 & 0.50 \\
\hline $\mathrm{WO}_{2}$ & 0.57 & 0.50 & 1.08 & 0.76 & 1.00 & 0.50 & 1.08 & 2.00 & 2.00 & 2.00 & 0.76 & 1.38 & 0.66 & 0.50 & 0.94 & 0.66 & 0.66 & 1.08 & 1.08 \\
\hline $\mathrm{ST}_{1}$ & 0.57 & 2.00 & 0.50 & 0.50 & 2.00 & 0.57 & 1.00 & 1.38 & 1.50 & 1.00 & 0.57 & 1.00 & 0.66 & 0.57 & 0.87 & 0.57 & 0.57 & 0.50 & 1.08 \\
\hline $\mathrm{ST}_{2}$ & 1.38 & 1.38 & 1.08 & 2.00 & 2.00 & 0.57 & 0.50 & 0.87 & 0.87 & 1.02 & 0.57 & 1.50 & 0.57 & 0.57 & 1.38 & 0.66 & 0.66 & 2.00 & 2.00 \\
\hline $\mathrm{WT}_{1}$ & 1.08 & 0.57 & 1.38 & 0.57 & 0.66 & 2.00 & 1.08 & 2.00 & 1.38 & 0.94 & 1.00 & 1.00 & 1.18 & 1.00 & 2.00 & 2.00 & 1.38 & 1.38 & 1.28 \\
\hline$\sum \mathbf{P}_{\mathrm{ij}}$ & 9.84 & 7.93 & 9.36 & 7.64 & 9.39 & 8.81 & 7.74 & 10.22 & 9.41 & 10.74 & 7.91 & 10.38 & 7.31 & 7.15 & 9.86 & 6.39 & 8.54 & 8.83 & 9.59 \\
\hline
\end{tabular}




\section{Table 2: Normalized Matrix}

\begin{tabular}{|c|c|c|c|c|c|c|c|c|c|c|c|c|c|c|c|c|c|c|c|}
\hline $\begin{array}{c}\text { Criteria } \\
/ \\
\text { Options }\end{array}$ & $S_{1}$ & $S_{2}$ & $S_{3}$ & $S_{4}$ & $\mathbf{S}_{5}$ & $\mathbf{W}_{1}$ & $\mathbf{W}_{2}$ & $\mathbf{W}_{3}$ & $W_{4}$ & $\mathbf{O}_{1}$ & $\mathbf{O}_{2}$ & $\mathbf{O}_{3}$ & $\mathbf{O}_{4}$ & $\mathbf{O}_{5}$ & $\mathbf{T}_{1}$ & $\mathbf{T}_{2}$ & $\mathbf{T}_{3}$ & $\mathbf{T}_{4}$ & $\mathbf{T}_{5}$ \\
\hline $\mathrm{SO}_{1}$ & 0.13 & 0.12 & 0.14 & 0.26 & 0.21 & 0.07 & 0.07 & 0.14 & 0.07 & 0.12 & 0.25 & 0.19 & 0.15 & 0.28 & 0.07 & 0.09 & 0.18 & 0.14 & 0.08 \\
\hline $\mathrm{SO}_{2}$ & 0.20 & 0.06 & 0.12 & 0.08 & 0.06 & 0.17 & 0.13 & 0.11 & 0.05 & 0.19 & 0.06 & 0.19 & 0.27 & 0.07 & 0.15 & 0.12 & 0.14 & 0.12 & 0.14 \\
\hline $\mathrm{SO}_{3}$ & 0.20 & 0.16 & 0.21 & 0.08 & 0.07 & 0.11 & 0.06 & 0.05 & 0.11 & 0.05 & 0.25 & 0.10 & 0.07 & 0.14 & 0.10 & 0.08 & 0.13 & 0.11 & 0.16 \\
\hline $\mathrm{WO}_{1}$ & 0.10 & 0.10 & 0.10 & 0.09 & 0.05 & 0.23 & 0.26 & 0.10 & 0.16 & 0.19 & 0.06 & 0.05 & 0.09 & 0.14 & 0.15 & 0.10 & 0.18 & 0.06 & 0.05 \\
\hline $\mathrm{WO}_{2}$ & 0.06 & 0.06 & 0.12 & 0.10 & 0.11 & 0.06 & 0.14 & 0.20 & 0.21 & 0.19 & 0.10 & 0.13 & 0.09 & 0.07 & 0.10 & 0.10 & 0.08 & 0.12 & 0.11 \\
\hline $\mathrm{ST}_{1}$ & 0.06 & 0.25 & 0.05 & 0.07 & 0.21 & 0.07 & 0.13 & 0.14 & 0.16 & 0.09 & 0.07 & 0.10 & 0.09 & 0.08 & 0.09 & 0.09 & 0.07 & 0.06 & 0.11 \\
\hline $\mathrm{ST}_{2}$ & 0.14 & 0.17 & 0.12 & 0.26 & 0.21 & 0.07 & 0.06 & 0.09 & 0.09 & 0.10 & 0.07 & 0.14 & 0.08 & 0.08 & 0.14 & 0.10 & 0.08 & 0.23 & 0.21 \\
\hline $\mathrm{WT}_{1}$ & 0.11 & 0.07 & 0.15 & 0.08 & 0.07 & 0.23 & 0.14 & 0.20 & 0.15 & 0.09 & 0.13 & 0.10 & 0.16 & 0.14 & 0.20 & 0.31 & 0.16 & 0.16 & 0.13 \\
\hline
\end{tabular}

Table 3:Entropy indices, degree of deviation and normalized weights of criteria

\begin{tabular}{|c|c|c|c|c|c|c|c|c|c|c|c|c|c|c|c|c|c|c|c|}
\hline Criteria & $S_{1}$ & $S_{2}$ & $\mathbf{S}_{3}$ & $S_{4}$ & $S_{5}$ & $W_{1}$ & $\mathbf{W}_{2}$ & $\mathbf{W}_{3}$ & $W_{4}$ & $\mathbf{O}_{1}$ & $\mathbf{O}_{2}$ & $\mathbf{O}_{3}$ & $\mathbf{O}_{4}$ & $\mathbf{O}_{5}$ & $\mathbf{T}_{1}$ & $\mathbf{T}_{2}$ & $\mathbf{T}_{3}$ & $\mathbf{T}_{4}$ & $\mathbf{T}_{5}$ \\
\hline $\begin{array}{c}\text { Entropy of } \\
\text { criteria(Ej) }\end{array}$ & 0.96 & 0.94 & 0.97 & 0.92 & 0.93 & 0.93 & 0.95 & 0.96 & 0.96 & 0.96 & 0.92 & 0.96 & 0.95 & 0.94 & 0.97 & 0.94 & 0.97 & 0.96 & 0.97 \\
\hline $\begin{array}{l}\text { Degree of } \\
\text { deviation of } \\
\text { criteria (dj) }\end{array}$ & 0.04 & 0.06 & 0.03 & 0.08 & 0.07 & 0.07 & 0.05 & 0.04 & 0.04 & 0.04 & 0.08 & 0.04 & 0.05 & 0.06 & 0.03 & 0.06 & 0.03 & 0.04 & 0.03 \\
\hline $\begin{array}{l}\text { Normalized } \\
\text { weight of } \\
\text { criteria (Wj) }\end{array}$ & 0.05 & 0.06 & 0.03 & 0.09 & 0.08 & 0.07 & 0.05 & 0.04 & 0.04 & 0.04 & 0.09 & 0.04 & 0.06 & 0.06 & 0.03 & 0.06 & 0.03 & 0.04 & 0.03 \\
\hline
\end{tabular}


Table 4: Decision matrix in Promethee method

\begin{tabular}{|c|c|c|c|c|c|c|c|c|c|c|c|c|c|c|c|c|c|c|c|}
\hline Criteria & $\mathbf{S}_{1}$ & $\mathbf{S}_{2}$ & $\mathbf{S}_{3}$ & $S_{4}$ & $S_{5}$ & $w_{1}$ & $\mathbf{W}_{2}$ & $\mathbf{W}_{3}$ & $\mathbf{W}_{4}$ & $\mathbf{O}_{1}$ & $\mathbf{O}_{2}$ & $\mathbf{O}_{3}$ & $\mathbf{O}_{4}$ & $\mathbf{O}_{5}$ & $\mathbf{T}_{1}$ & $\mathbf{T}_{2}$ & $\mathbf{T}_{3}$ & $\mathbf{T}_{4}$ & $\mathbf{T}_{5}$ \\
\hline $\begin{array}{c}\text { Function } \\
\text { type }\end{array}$ & 3 & 3 & 3 & 3 & 3 & 3 & 3 & 3 & 3 & 3 & 3 & 3 & 3 & 3 & 3 & 3 & 3 & 3 & 3 \\
\hline $\max / \min$ & $\max$ & $\max$ & $\max$ & $\max$ & $\max$ & $\min$ & $\min$ & $\min$ & $\min$ & Max & $\max$ & $\max$ & $\max$ & $\max$ & $\min$ & $\min$ & $\min$ & $\min$ & $\min$ \\
\hline $\mathrm{SO}_{1}$ & 8.65 & 6.95 & 7.65 & 7.32 & 7.65 & 1.26 & 1.82 & 1.82 & 1.82 & 6.95 & 8.32 & 9.00 & 6.65 & 9.00 & 1.00 & 1.82 & 2.88 & 2.62 & 2.88 \\
\hline $\mathrm{SO}_{2}$ & 8.65 & 7.32 & 4.93 & 5.65 & 1.00 & 1.82 & 1.59 & 2.62 & 1.82 & 8.32 & 4.93 & 9.00 & 8.32 & 4.31 & 1.00 & 1.26 & 1.82 & 1.82 & 1.26 \\
\hline $\mathrm{SO}_{3}$ & 8.65 & 8.65 & 8.65 & 6.95 & 6.65 & 5.94 & 3.91 & 1.82 & 1.00 & 7.65 & 8.32 & 4.93 & 5.94 & 2.88 & 2.00 & 2.62 & 1.82 & 2.62 & 3.91 \\
\hline $\mathrm{WO}_{1}$ & 7.65 & 4.64 & 7.96 & 3.91 & 5.94 & 8.65 & 8.65 & 1.59 & 2.29 & 8.65 & 2.29 & 4.64 & 1.26 & 3.30 & 2.29 & 1.00 & 1.26 & 1.00 & 1.82 \\
\hline $\mathrm{WO}_{2}$ & 1.82 & 5.94 & 1.82 & 6.95 & 1.82 & 4.00 & 3.30 & 1.00 & 8.32 & 9.00 & 1.82 & 6.95 & 3.63 & 2.62 & 1.00 & 4.31 & 3.00 & 2.00 & 3.91 \\
\hline $\mathrm{ST}_{1}$ & 6.95 & 9.00 & 1.82 & 2.00 & 8.32 & 1.59 & 2.00 & 2.29 & 2.62 & 7.65 & 3.30 & 5.94 & 3.30 & 2.00 & 1.00 & 3.30 & 2.00 & 2.29 & 1.26 \\
\hline $\mathrm{ST}_{2}$ & 6.65 & 7.96 & 5.94 & 8.65 & 8.65 & 3.00 & 1.00 & 2.00 & 2.00 & 6.95 & 4.93 & 3.63 & 4.93 & 3.91 & 1.82 & 2.29 & 1.59 & 8.32 & 9.00 \\
\hline $\mathrm{WT}_{1}$ & 7.96 & 6.95 & 5.94 & 3.91 & 1.59 & 8.65 & 3.91 & 8.65 & 2.88 & 7.65 & 5.94 & 7.65 & 7.00 & 6.95 & 9.00 & 8.32 & 2.88 & 1.82 & 6.95 \\
\hline
\end{tabular}

